\title{
A Review of Weed Control Practices in Landscape Planting Beds: Part I-Nonchemical Weed Control Methods
}

\author{
S. Christopher Marble ${ }^{1,3}$ \\ Department of Environmental Horticulture, CLCE, IFAS, University of \\ Florida Mid-Florida Research and Education Center, 2725 South Binion \\ Road, Apopka, FL 32703
}

\author{
Andrew K. Koeser ${ }^{1}$ and Gitta Hasing ${ }^{2}$ \\ Department of Environmental Horticulture, CLCE, IFAS, University of \\ Florida Gulf Coast Research and Education Center, 14625 County Road \\ 672, Wimauma, FL 33598
}

Additional index words. homeowner, horticulture, landscape fabric, mulch

\begin{abstract}
Weed control continues to be one of the most expensive and time consuming aspects of landscape maintenance. Many homeowners are becoming more interested in nonchemical pest-management strategies due to increasing concern over the environmental impact of pesticide use. Nonchemical landscape weed control can be achieved using mechanical disruption (e.g., mowing, hand-pulling, hoeing, and tilling), physical barriers, or cultural control methods (e.g., mulching and plant selection). However, the best results are almost always achieved when employing a variety of methods (often involving chemical control methods). In adopting a weed control strategy, client expectations and weed tolerances must be addressed. While a virtually weed-free landscape is possible without the use of herbicides, this goal often requires a significant amount of time and money, and requires more planning to be successful. The goal of this manuscript is survey the literature pertaining to nonchemical weed control in landscape planting beds and determine: 1) the most effective strategies; 2) the advantages and disadvantages of common practices; and 3) highlight areas where research is needed or improvements could be made.
\end{abstract}

The landscape maintenance sector of the U.S. green industry generated over $\$ 58$ billion in sales and employed over 1.1 million people in 2007 (Hodges et al., 2011a). In Florida alone, the landscape industry employed over 100,000 people and generated over $\$ 6$ billion in sales in 2010, with a majority of these sales coming from the landscape maintenance sector (Hodges et al., 2011b). The benefits of well-maintained urban and suburban landscapes, especially those with large-stature trees, have been thoroughly documented and include energy conservation (McPherson and Rowntree, 1993; Simpson, 1998), carbon sequestration (McPherson, 1998), reductions in air pollution (Scott et al., 1998), and improvements in quality of life (Sullivan and Kuo, 1996; Ulrich, 1986). Landscapes can also offer financial benefits by significantly increasing residential property valuations and rental prices for office buildings (Laverne and WinsonGeideman, 2003; Morales, 1980; Payne,

\footnotetext{
Received for publication 7 Jan. 2015. Accepted for publication 3 Apr. 2015.

We thank the University of Florida Center for Landscape Conservation and Ecology for financial support.

${ }^{1}$ Assistant Professor.

${ }^{2}$ Senior Biological Scientist.

${ }^{3}$ To whom reprint requests should be addressed; e-mail marblesc@ufl.edu.
}

1973; Taylor and Smith, 2000) and singlefamily homes (Donovan and Butry, 2011). A report by the Council of Tree and Landscape Appraisers (2000) suggests that well-maintained landscapes can contribute up to $20 \%$ of the value of residential properties. However, to provide all of these benefits, landscapes must be installed correctly and properly maintained (Henry, 1994).

Weed control is an important component in landscape maintenance from both an aesthetic and biological perspective. From a biological perspective, weed control is critical to landscape survival in the first year after transplanting as installed plants are not yet competitive and weed pressure is often greater following site disturbance (Davison, 1983). Weeds can outcompete landscape plants for space, light, moisture, and nutrients (Messenger, 1976; Nielson and Wakefield, 1978) and have been shown to reduce the survival rate of young trees and other ornamentals (Davies, 1985). In addition, over 240 weed species have been found to have allelopathic properties (Colquhoun, 2006), of which some have been reported to have negative effects on ornamental plant growth (Kolb, 1988).

From an aesthetic perspective, outdoor residential environments are extremely important to homeowners (Blaine et al., 2012). Landscape maintenance is often viewed as investment in capital as homes usually represent a homeowners' most valuable asset.
The expectation of financial return on the time and money invested in maintenance serves as a compelling incentive for many property owners (Robbins et al., 2001). Homeowners realize that the exterior of their home is all that most people will see, and many use their landscape to demonstrate expertise, care, and social status (Larson et al., 2009; Nassauer, 1988; Robbins and Sharp, 2003a). More pragmatically, homeowners may also have to control weeds to follow local ordinances and homeowner association regulations to avoid fines (Martin et al., 2003; Rappaport, 1992; Robbins, 2007).

In comparison with turf areas and agronomic crops, there are relatively few herbicide options for selective weed control in and around ornamental plantings (Fennimore and Doohan, 2008). Many herbicides can cause significant damage to ornamentals (Adams, 1990). Environmental and safety concerns have also caused an increased preference for "environmentally friendly," integrated pest management (IPM), or nonchemical approaches to pest control in home landscapes and gardens (Matheny, 2009). Many municipalities in Canada and parts of the United States are now banning or restricting the use of herbicides and other "cosmetic" pesticides, specifically around schools and public buildings (Cole et al., 2011; Robbins and Sharp, 2003b; Sandberg and Foster, 2005). Due to these increasing regulations, many landscapers are being forced to control weeds using only nonchemical control strategies. Homeowners and landscapers have a variety nonchemical weed control tools to choose from, but the most economical and effective weed control will be achieved when combining a variety of methods in each area (i.e., IPM). Home lawns or turf areas are often the most valued portions of landscapes (Blaine et al., 2012), thus reviews have been previously published covering nonchemical weed control methods in turf (Busey, 2003). The purpose of this manuscript is to provide a review nonchemical weed control strategies in landscape planting beds and identify areas in which further research and improvements are needed or where current practices could potentially be improved.

\section{Mulching}

The cornerstone of a landscape weed control program is the use of organic or inorganic mulches. Mulches serve several functions in the landscape including moisture retention (Iles and Dosmann, 1999), erosion and compaction reduction (Mannering and Meyer, 1963; Oliveira and Merwin, 2001), soil temperature optimization (Einert et al., 1975), and ornamental plant growth enhancement (Watson, 1988). While these are noteworthy benefits, mulch is typically applied to landscape beds for aesthetics and weed suppression. Depending upon the type of mulch that is used, weed growth can be reduced by means of light exclusion, reduction of available air and water in seedbed, allelopathic 
chemical leaching, or the creation of a physical barrier (Chalker-Scott, 2007).

Organic mulch. In landscape plantings, Skroch et al. (1992) evaluated weed control using five different organic mulches [i.e., pinebark (unspecified species), hardwood bark (unspecified species), cedar chips (unspecified species), shortleaf pine needles (Pinus echinata Mill.), and longleaf pine needles (Pinus palustris Mill.)]. Weed counts of tall fescue (Festuca arundinacea Schreb.), vetch (Vicia spp.), common blue violet (Viola papilionacea Pursh), wild garlic (Allium vineale L.), bermudagrass [Cynodon dactylon (L.) Pers.], and yellow nutsedge (Cyperus esculentus L.) were reduced by $50 \%$ in mulched plots compared with the control (nonmulched) with plots. Similarly, a comparison of 15 different organic landscape mulches showed that all provided better weed control than nonmulched plots, but few differences were observed in weed suppression between different mulch types (Stinson et al., 1990). Organic mulches have even been shown to reduce emergence and establishment of some of the most troublesome weeds. In a study by Chen et al. (2013), pine straw, pine bark nuggets, and cypress mulch reduced yellow nutsedge shoot densities by $40 \%$ to $60 \%$ compared with bare-soil (no mulch) plots, although the best control was achieved when a herbicide (S-ethyl dipropylthiocarbamate) was applied in combination with mulch.

Organic mulches have been shown to prevent weed germination and growth in a variety of other horticultural applications. In container plant production, Cochran et al., (2009) reported that a $2.5-\mathrm{cm}$ ( 1 inch) layer of pine bark mini-nuggets reduced weed counts of eclipta (Eclipta prostrata L.) by $87 \%$ and spotted spurge (Chamaesyce maculata L.) by $90 \%$ compared with a nonmulched control. Pinebark mini-nuggets were also shown to provide season-long weed control of bittercress (Cardamine hirsuta L.) when applied at a depth of $7.6 \mathrm{~cm}$ (3 inches), without affecting growth of oakleaf hydrangea (Hydrangea quercifolia Bartr.) or Natchez crapemyrtle (Lagerstroemia indica 'Natchez') (Richardson et al., 2008). Similarly, an earlier study by Wilen et al. (1999) found a 92\% reduction in weeds in container-grown plants that were mulched compared with plants left bare.

While organic mulches improve soil and plant health, provide weed control, and are aesthetically pleasing, research has shown the right type of mulch must be used and it should be applied at an adequate depth (Greenly and Rakow, 1995). Fine textured and nutrient-dense materials such as composts are not suitable for weed control and may act as a potential seed bank for weed species (Chalker-Scott, 2007) and possibly increase weed germination (Maynard, 1998). Cregg and Schutzki (2009) conducted a study to determine the impact of common landscape mulches (pinebark, hardwood fines, cypress mulch, and color enhanced ground pallets) on weed control and the growth of eight different landscape species (Euonymus alatus 'Compactus', Spiraea bumalda 'Goldflame', Weigela florida 'Java red', Taxus.media 'Runyan', Thuja occidentalis 'Golden Globe', Hydrangea paniculata 'Tardiva', Viburnum dentatum 'Synnestvedt', and Viburnum trilobum 'Compactum'). All mulch materials provided significantly better control of weeds such common dandelion (Taraxacum officinale F.H. Wigg), redroot pigweed (Amaranthus retroflexus L.), horseweed (Conyza canadensis L.), and annual grasses (unspecified species) compared with nonmulched treatments and improved plant growth. However, it was also noted that populations of annual sowthistle (Sonchus oleraceus L.) were greater on plots mulched with cypress, ground pallets, or hardwood fines than in nonmulched plots. The authors noted that these mulch materials may have provided a suitable seedbed for this species, or were not applied at an adequate depth. Other studies have also shown that only applying a thin layer of mulch can increase weed germination (Kuhns, 1992). Greenly and Rakow (1995) compared the effects of three mulch depths $[7.5 \mathrm{~cm}$ (3 inches), $15 \mathrm{~cm}$ (6 inches), and $25.5 \mathrm{~cm}$ (10 inches)] on weed cover $(0-100 ; 0=$ no weed coverage, and $100=$ full weed coverage) using two types of mulch (chipped pine chips and shreddedhardwood chips) and compared a nonmulched control. Weed coverage was significantly affected by mulch depth. Plots with no mulch had an average percent cover of $\approx 95 \%$ compared with about $25 \%$ coverage at the $7.5 \mathrm{~cm}$ depth, $10 \%$ at the $15 \mathrm{~cm}$, and less than $5 \%$ at the $25.5 \mathrm{~cm}$ depth. A review of mulching practices led ChalkerScott (2007) to recommend organic mulching depths above $7.6 \mathrm{~cm}$ ( 3 inches) to provide effective weed control without causing damage to ornamental plants. When weeds are able to successfully emerge through mulch materials, it is primarily due to their ability to grow around mulch particles in limited light conditions as shown by models developed by Teasdale and Mohler (1999). In most cases, coarser mulches with larger particle sizes provide the best weed control because they reduce more light and dry out faster than smaller particle materials and create a less conducive environment for seed germination (Cahill et al., 2005; Froment et al., 2000). Billeaud and Zajicek (1989) compared effects of screened pine bark [0.6-0.9 cm (0.20.4 inch) particle size], hardwood [primarily oak, $0.6-7.5 \mathrm{~cm}(0.2-3$ inches $)$ particle size], cypress $[0.6-7.5 \mathrm{~cm}(0.2-3$ inches $)$ particle size], and decorative pine bark nuggets [7.5$10 \mathrm{~cm}$ (3-4 inches) particle size]. Results showed that weed control increased as particle size increased. There were significant reductions in mean weed counts (listed parenthetically) when using decorative pine bark nuggets (1.42), hardwood (4.20), and cypress (5.6) when compared with screen pine bark (10.36) which had similar weed counts to nonmulched beds (15.03).

There are some drawbacks associated with the use of organic mulches for weed control. Some mulch types can degrade quickly, requiring the need for frequent reapplication, and many can attract unwanted insect pests or termites (Duryea et al., 1999a, 1999b; Gill et al., 2011). In certain situations, organic mulches may need to be applied at depths as high as $10-15 \mathrm{~cm}$ (4-6 inches) to provide effective weed control (ChalkerScott, 2007); however, mulch applied at this level has the potential to damage some ornamental plants (Billeaud and Zajicek, 1989). Mulches can be contributors of weed seed. While some reports show that weed seed in processed pine bark is usually minimal (Norcini et al., 2010), anecdotal evidence suggests mulches from less reputable sources or products that contain yard clippings or waste can contain viable weed seeds or vegetative portions of invasive species (Chalker-Scott, 2007).

Inorganic mulch. Inorganic mulches generally do not break down over time, are virtually pest free, and often can be used at comparatively lower depths while still providing adequate weed control. In a weed control study in urban landscape plantings, gravel, quarry dust, and sand all reduced total weed biomass in comparison with control treatments (no mulch), though weed biomass was reduced the most in gravel treatments (Hanim et al., 2014). Winkel et al. (1995) reported gravel layers of 4-5 cm (1.5-2 inches) prevented emergence of galleta grass (Hilaria jamesii Torr.). While effective, rock and stone materials are usually associated with a much higher installation cost and are more difficult to transport and spread on site given their weight. These materials also do not help build up the soil by adding organic matter as organic mulches do.

One of the most common types of inorganic mulches used in landscape planting beds are different types of geotextile or landscape films or fabrics. Many of these materials have been evaluated with varying levels of success. Many adverse effects on landscape plant growth have been reported with the use of impermeable landscape plastic materials including restricted root growth, water and nutrient stress, and reduced soil oxygen and they are no longer recommended (Appleton et al., 1990; Robinson, 1988; Smith, 1979; Whitcomb, 1979). Landscape fabrics, or geotextiles, are woven materials that allow air and water movement, and have been shown to provide adequate weed control in the landscape. Martin et al. (1987) evaluated nine different polypropelene fabrics and reported variable results depending upon weed species and type of fabric used (manufacturer). Yellow nutsedge, bermudagrass (Cynodon dactylon L.), johnson grass (Sorghum halepense L.), and pigweed (Amaranthus spp.) emerged through seven of the nine fabrics while sicklepod (Arabis canadensis L.) and morning glory (Ipomoea spp.) were inhibited by all nine fabrics. Skroch et al. (1992) evaluated various organic mulches on top of two different landscape fabrics (black polyethylene and woven polypropylene) and reported that both fabrics improved weed control compared with use of organic mulch alone. 
At the conclusion of the study (630 d after initiation), polyethylene used in combination with organic mulch provided complete weed control while polyprolene was less effective for controlling perennial weed species; however, the authors noted that the polyethylene fabric used was nonporous and had been previously shown to reduce plant growth. In almost all cases, these fabrics are only effective for a short period of time and do not control perennial weeds (Appleton and Derr, 1989; Martin et al., 1987). Mulch is applied over these fabrics for aesthetic reasons, to prevent ultraviolet degradation, and improve aesthetics (Skroch et al., 1992), but weeds will inevitably begin germinating on top of fabrics over time as mulches break down. As these weed seedlings grow, they can root into the fabric increasing the time needed to hand weed (Derr and Appleton, 1989).

The use of landscape fabrics also increases installation costs by requiring multiple materials (e.g., mulch, staples, and fabrics) to be aesthetically acceptable. Replacing degraded fabrics is time consuming and expensive. If not careful, landscape fabric removal can damage nearby ornamentals that often root into the fabric (Appleton et al., 1990). Furthermore, these materials are designed to be installed before planting, and proper installation in existing landscapes is difficult. For these reasons, landscape fabrics are typically not recommended as a long-term approach in landscape beds unless they are installed and maintained correctly.

Recycled rubber materials are another type of inorganic mulch. These products are typically cut into pieces that resemble organic mulch materials (e.g., pine bark nuggets or pine straw) and dyed to give it a more natural appearance. This offers the benefit of a product which resembles organic mulches but resists degradation. Although, research is lacking on many of the newer products available, a report by Calkins et al. (1996) showed that hardwood bark mulch applied at a depth of 10-15 cm (4-6 inches) provided better weed control than a rubber tire chip mulch applied at a depth of 8-10 cm (3-4 inches). While offering a first direct comparison, mulch type is confounded with application depth in this study.

Several environmental and safety concerns have risen with use of these rubber by-products as they may leach high levels of zinc and other heavy metals found in tires such as selenium, lead and cadmium (Crampton et al., 2014; Kanematsu et al., 2009; Sadiq et al., 1989; Smolders and Degryse, 2002) and have increased flammability compared with organic mulches such as hardwood bark, pine bark nuggests, or cocoa shells (Steward et al., 2003). Almost no research has been conducted to determine the effects of rubber mulch on plant growth in the landscape. When used as a container media amendment, rubber mulches can reduce plant growth and vigor primarily due to zinc toxicity (Bowman et al., 1994; Bush et al., 2006). It is unknown if use of rubber materials as a mulch would have similar effects on landscape plants when only applied on the soil surface as opposed to being in direct contact with plant roots (as a container media amendment). Additionally, rubber mulches will likely be much more expensive, at least initially, than any other widely available organic mulch material. In central Florida, the retail cost (bagged or bulk) of rubber mulch generally ranges from $\$ 8$ to $\$ 12$ or per $0.03 \mathrm{~m}^{2}\left(1 \mathrm{ft}^{3}\right)$ compared with $\$ 1$ to $\$ 2$ for pine bark nuggets or pine straw. Further research is needed to determine environmental impacts and the effects of rubber mulch on plant growth before recommendations can be made. Based on currently available research, these products may be more suitable for nonlandscaped areas such as walkways and playgrounds as opposed to being used in ornamental landscape planting beds until further research is conducted.

Plant selection. The selection of insect and disease resistant ornamental species is an important aspect in IPM. Ornamental selection is typically not applicable for controlling weeds, with the exception of turf and groundcover areas in which species selection is important to outcompete prevalent weeds in the area (Busey, 2003). There are no "weed resistant" plants in the classical sense; however, when parasitic weeds are present, planting resistant species can help improve weed control. Dodder (Cuscuta spp.) is a summer annual obligate parasitic weed and is often a difficult and expensive weed to control in annual bedding plants. Neal (2006) evaluated dodder (Cuscuta japonica Choisy) host preference for commonly planted landscape annual species. Results showed that petunia (Petunia $\times$ 'Wave White'), vinca (Catharanthus roseus 'Pacific White'), impatiens (Impatiens $\times$ 'Dazzler Coral'), and coleus (Coleus $\times$ hybridus) where the most susceptible species for infestations, whereas scaevola (Scaevola aemula R. Br.), begonia (Begonia semperflorens-cultorum 'Super Olympia White'), gomphrena (Gomphrena globosa 'Lavender Lady'), ornamental sweetpotato (Ipomoea batatas 'Sweet Caroline Burgundy'), and verbena (Verbena hybrida 'Aztec Silver Magic') were the least susceptible. Other parasitic weeds such as mistletoes (Viscum spp., Arceuthobium spp., etc.) may also have preferred hosts (Norton and Carpenter, 1998). Although most weeds are not parasitic, planting nonpreferred hosts could be successful in some specific situations where parasitic weeds have historically been a problem. More data are needed in ornamental plantings before strong recommendations can be made, including if varietal differences exist in host specificity and if there are host preferences between related plant species (Neal, 2006).

Although often ignored in the literature, another case in which ornamental species selection could have an impact on weed growth is the use of groundcovers or other densely growing plants that can shade out weed species and reduce their growth. In areas not suitable for turf establishment, one alternative is the use of ornamental groundcovers, which are any species that have a trailing or spreading growth habit and cover the soil surface. A considerable amount of research has been published concerning the growth or landscape performance of different groundcover species (Niu and Rodriguez, 2006; Pittenger et al., 2001; Zhang and Xia, 2003). A recurring theme in much of the research involves evaluating different groundcover species for low maintenance characteristics, such as salinity or drought tolerance (Morosz, 2004; Still and Davies, 1993), but very little work has focused on the ability of various groundcovers to outcompete weeds, which is an important component of overall maintenance costs. Eom et al. (2005) evaluated 15 herbaceous perennials as weed suppressive groundcovers. Of the 15 species evaluated, four species including Alchemillia mollis, Nepeta $\times$ faassenii, Phlox subulata, and Solidago sphacelata were strongly weed suppressive, which was attributed to dense foliage and early emergence in the spring. A more recent study by Foo et al. (2011) examined 12 ornamental groundcovers (i.e., Acaena inermis 'Purpurea', Ajuga reptans 'Caitlin's Giant', Coprosma acerosa 'Taiko', Grevillea lanigera 'Little Drummer Boy', Juniperus procumbens 'Nana', Lithodora diffusum 'Grace Ward', Muhlenbeckia axillaris, Ophiopogon planiscapus, Persicaria capitatum, Pimelea prostrata 'Anatoki', Sedum mexicanum 'Acapulco Gold', and $V e$ ronica peduncularis 'Oxford Blue') to assess their ability to suppress weed growth. Acaena inermis and Muhlenbeckia axillaris quickly covered the plots within 12 months and effectively prevented weed germination during the evaluation period. Persicaria capitatum also grew quickly but was unsuitable for weed suppression as it died back each winter. Currently there is little information available on the ability of popular, permanent groundcover species to suppress weeds. As groundcovers are becoming a more popular alternative to turf in the landscape due to their low maintenance characteristics, more research is needed to select the most appropriate species for different sites in various regions, not only for irrigation, fertilization, light, or salt tolerances, but for their ability to suppress weeds. Having the ability to choose densely growing groundcovers that can offer some degree of weed control will have a major impact on reducing the overall maintenance of a landscape planting and could prove to be an important component of nonchemical weed control in the landscape. However, it should be noted that many groundcover species that can provide weed suppression have the ability to become invasive themselves, such as Liriope spicata and others (Adams et al., 2013). Further work is needed to identify groundcover species which can outcompete certain weed species while not becoming invasive or naturalized.

\section{Other Nonchemical Control Methods}

Hand weeding and cultivation. Other nonchemical methods that have proven to be effective include hand weeding and cultivation 
or tillage (MacRae et al., 2010). Hand weeding is the most time-consuming weed control method (Case et al., 2005) for large planting beds and when severe infestations are present, it is by far the most expensive method from a professional landscape contractor's (i.e., labor) perspective. Hand tools or equipment can be used to cultivate or till the soil to physically remove or destroy weeds. While effective and less labor intensive than hand weeding in heavy infestations, tilling or cultivating can still require a great deal of time, and can damage nearby ornamentals, especially underground storage organs and shallow roots (Calkins et al., 1996). Cultivation can also to degrade soil structure by increasing compaction and erosion over time (Somireddy, 2012). Furthermore, the mechanical disruption does not prevent other weed seeds from germinating and may offer limited control or increase populations of weed species which spread via horizontal roots, rhizomes, or stolons (Froud-Williams et al., 1981).

Thermal weed control. Thermal weed control, which uses some form of heat, such as steam or flame from a propane burner, has proven successful in row crop production (Parish, 1990). Flaming can provide suppression of many different annual species, but is less effective on larger weeds, perennials, and grass species (Ascard, 1995). This process can also be dangerous, especially during dry conditions and can damage nearby plants and other materials (i.e., irrigation heads, hoses, lawn ornaments, etc.). One area in which thermal methods can offer weed control without fear of damaging nearby ornamentals is in and around hardscapes and other nonplanted areas. In a study by Kristoffersen et al. (2008), four different thermal treatments including flaming, steam, hot air, and hot water were compared with a mechanical control method (steel brushes) and a nontreated control for weed control in traffic islands (paved areas filled with gravel). Results showed that all treatments significantly reduced weed cover compared with nontreated areas; however, hot water (heated to $95^{\circ} \mathrm{C}$ and mixed with foam made of coconut and maize oil) was the most effective treatment and all thermal treatments offered better control than brushing. Solarization is another form of thermal weed control and involves heating the soil surface using plastic sheets on moist soil to trap solar radiation (Horowitz et al., 1983). Solarization has been shown to provide effective control of many different weed species including pigweeds (Amaranthus spp.), common purslane (Portulaca oleracea), and henbit (Lamium amplexicaule) (Horowitz et al., 1983), but requires several weeks and sunny, warm weather to be effective. While several thermal control options can be effective, they will usually require multiple applications or treatments each season, extended periods of time (for solarization), and could damage nearby ornamentals or other materials (irrigation heads, hoses, etc.). Further, special equipment needed is often expensive and impractical for multiple applications, thus thermal weed control may only be feasible in very specific situations and its potential for wide-spread use in the landscape is currently minimal (Rask and Kristoffersen, 2007).

Irrigation and fertilizer placement. Fertilizer placement has been shown to reduce weed growth in numerous production systems. By placing fertilizer near the root zone of crops, less fertilizer is available for weed growth and crop plants gain a competitive advantage (Di Tomaso, 1995). Banding fertilizer, or placing fertilizer near crop roots as opposed to broadcasting over the entire crop area has been shown to reduce weed growth in numerous agronomic studies (Chauhan and Ahugho, 2013; Kirkland and Beckie, 1998; Mashingaidze et al., 2012). Fertilizer placement has been shown to have a significant impact on weed growth in containergrown ornamental plant production (Fain et al., 2003). In a container study, Altland et al. (2004) reported that dibbling fertilizer (placing fertilizer directly beneath root ball) significantly reduced weed germination compared with incorporating (mixing fertilizer in with media) or top-dressing (placing fertilizer on container media surface). In a similar study, Broschat and Moore (2003) reported less weed growth in container-grown ornamentals when fertilizer was layered just beneath the root ball (a modified dibble) compared with incorporation or topdressing. Few studies investigating the effects of fertilizer placement on weed growth in the landscape have been reported. In one landscape study, Broschat (2007) reported no difference in weed numbers when fertilizer was placed either above or below organic mulch layers; however, all fertilizer treatments were broadcast in this study. It is likely that fertilizer placement would have little effect on weed growth in most landscape situations; in most cases, landscape planting beds would have ample nutrient reserves needed to support growth of weed species that are adapted to poor soils. However, there could be a benefit of fertilizer placement with certain weed species such as pigweeds (Amaranthus spp.) which have been shown to dramatically increase in size with increasing nitrogen rates (Blackshaw et al., 2003).

Water placement (via microirrigation or drip or sub-irrigation systems) has been shown to reduce weed growth in container plant production. In a study by Wilen et al. (1999), sub-irrigation reduced weed growth in containers by $18 \%$ compared with surface irrigated (over-head) containers. In most cases, the effects of irrigation placement (overhead vs. sub-irrigation) on weed growth in and around ornamentals are only significant in container studies in which water is limited to the volume of the container and the soilless media (i.e., pine bark) quickly dries following irrigation. As has been shown in field experiments (Das and Yaduraju, 1999) irrigation placement would likely be ineffective as a weed control measure; many weed species thrive in less than ideal environments, and many can survive and reproduce under very dry conditions. However, irrigation placement may have the potential to reduce occurrence of certain weed species such as eclipta (Eclipta prostrata L.) which require high moisture levels to germinate (Chauhan and Johnson, 2008).

\section{Conclusion}

There are multiple effective methods of nonchemical weed control in landscape planting beds and the best method will depend on weed species present, aesthetic appeal and preference, cost, and efficacy. With proper planning and utilization of multiple methods, satisfactory weed control can be achieved without the use of herbicides; however, solely using nonchemical methods will require a significant amount of time or labor, money, and constant scouting to decrease weed germination and growth before infestations become unmanageable. While numerous studies have been conducted on various nonchemical weed control methods, more research is needed, particularly in the landscape sector. Specific areas in which further research could lead to improvements in management techniques include side-byside comparisons of organic and inorganic mulches in terms of cost, durability, and control of specific weed species. Further work is also needed on the utilization of common groundcover species and their ability to outcompete and suppress weed growth in low maintenance landscapes. Other potential future research areas include parasitic weed (i.e., dodder and others), host specificity, and cultural control of weeds in the landscape by strategically placing water and nutrients nearby ornamental species and limiting the availability of these resources to weeds.

\section{Literature Cited}

Adams, D. 1990. Chemical weed control in containerized hardy ornamental nursery stock. Professional Hort. 4:70-75.

Adams, K.T., G.H. Gilliam, G.R. Wehtje, and S.F. Enloe. 2013. Postemergence control of Liriope spicata. Acta Hort. 1014:439-442.

Appleton, B.L. and J.F. Derr. 1989. Combining mulch with geotextiles for landscape weed control. Proc. Southern Nur. Assoc. Res. Conf. 34:262-265.

Appleton, B.L., J.F. Derr, and B.B. Ross. 1990. The effect of various landscape weed control measures on soil moisture, temperature, and tree root growth. J. Arbor. 16:264-268.

Altland, J.E., G.B. Fain, and K. Von Arx. 2004. Fertilizer placement and herbicide rate affect weed control and crop growth in containers. J. Environ. Hort. 22:93-99.

Ascard, J. 1995. Effects of flame weeding on weed species at different developmental stages. Weed Res. 35:397-411

Billeaud, L.A. and J.M. Zajicek. 1989. Influence of mulches on weed control, soil $\mathrm{pH}$, soil nitrogen content, and growth of Ligustrum japonicum. J. Environ. Hort. 7:155-157.

Blackshaw, R.E., R.N. Brandt, H.H. Jansen, T. Entz, C.A. Grant, and D.A. Derksen. 2003. Differential response of weed species to added nitrogen. Weed Sci. 51:532-539. 
Blaine, T.W., S. Clayton, P. Robbins, and P.S. Grewal. 2012. Homeowner attitudes and practices towards residential landscape management in Ohio, USA. Environ. Mgt. 50:257-271.

Bowman, D.C., R.Y. Evans, and L.L. Dodge. 1994. Growth of chrysanthemum with ground automobile tires used as a container soil amendment. HortScience 29:774-776.

Broschat, T.K. and K.A. Moore. 2003. Influence of fertilizer placement on plant quality, root distribution, and weed growth in container-grown tropical ornamental plants. HortTechnology 13:305-308.

Broschat, T.K. 2007. Effects of mulch type and fertilizer placement on weed growth and soil $\mathrm{pH}$ and nutrient content. HortTechnology 17:174-177.

Busey, P. 2003. Cultural management of weeds in turfgrass: A review. Crop Sci. 43:1899-1911.

Bush, E., A. Owings, and K. Leader. 2006. Foliar accumulation of zinc in tree species grown in hardwood bark media amended with crumb rubber. J. Plant Nutr. 26(7):1413-1425.

Cahill, A., L. Chalker-Scott, and K. Ewing. 2005. Wood-chip mulch improves plant survival and establishment at no-maintenance restoration site (Washington). Ecol. Res. 23:212-213.

Calkins, J.B., B.T. Swanson, and D.L. Newman. 1996. Weed control strategies for field grown herbaceous perennials. J. Environ. Hort. 14:221227.

Case, L.T., H.M. Mathers, and A.F. Senesac. 2005. A review of weed control practices in container nurseries. HortTechnology 15:535-545.

Chalker-Scott, L. 2007. Impact of mulches on landscape plants and the environment: A review. J. Environ. Hort. 25:239-249.

Chauhan, B.S. and S.B. Ahugho. 2013. Fertilizer placement affects weed growth and grain yield in dry-seeded rice (Oryza sativa L.) systems. Amer. J. Plant Sci. 4:1260-1264.

Chauhan, B.S. and D.E. Johnson. 2008. Influence of environmental factors on seed germination and seedling emergence of eclipta (Eclipta prostrata) in a tropical environment. Weed Sci. 56:383-388.

Chen, Y., R.E. Strahan, and R.P. Bracy. 2013. Effects of mulching and preemergence herbicide placement on yellow nutsedge control and ornamental plant quality in landscape beds. HortTechnology 23:651-658.

Cochran, D.R., C.H. Gilliam, D.J. Eakes, G.R. Wehtje, P.R. Knight, and J. Olive. 2009. Mulch depth affects weed seed germination. J. Environ. Hort. 2:85-90.

Cole, D.C., L. Vanderlinden, J. Leah, R. Whate, C. Mee, M. Bienefeld, S. Wanigaratne, and M. Campbell. 2011. Municipal bylaw to reduce cosmetic/non-essential pesticide use on household lawns: A policy implementation evaluation. Environ. Health 10:74.

Colquhoun, J.B. 2006. Allelopathy in weeds and crops: Myths and facts. Proc. Wisconsin Fert., Aglime, and Pest Mgt. Conf. 45:318-320.

Council of Tree and Landscape Appraisers. 2000. Guide for plant appraisal. 9th ed. Intl. Soc. Arbor., Champaign, IL.

Crampton, M., A. Ryan, C. Eckert, K.H. Baker, and D.S. Herson. 2014. Effects of leachate from crumb rubber and zinc in green roofs on the survival, growth, and resistance characteristics of Salmonella enterica subsp. enterica Serovar Typhimurium. Appl. Environ. Microbiol. 80: 2804-2810.

Cregg, B.M. and R. Schutzki. 2009. Weed control and organic mulches affect physiology and growth of landscape shrubs. HortScience 44: 1419-1424.
Das, T.K. and N.T. Yaduraju. 1999. Effect of weed competition on growth, nutrient uptake and yield of what as affected by irrigation and fertilizer. J. Agr. Sci. 133:45-51.

Davies, R.J. 1985. The importance of weed control and the use of tree shelters for establishing broadleaved trees on grass-dominated sites. Forestry 58:167-180.

Davison, J.G. 1983. Effective weed control in amenity plantings. HortScience 34:28-34.

Derr, J.F. and B.L. Appleton. 1989. Weed control with landscape fabrics. J. Environ. Hort. 7:129133.

Di Tomaso, J.M. 1995. Approaches for improving crop competitiveness through manipulation of fertilization strategies. Weed Sci. 43:491-497.

Donovan, G.H. and D.T. Butry. 2011. The effect of urban trees on the rental price of single-family homes in Portland, Oregon. Urban For. Urban Green. 10:163-168.

Duryea, M.L., R.J. English, and L.A. Hermansen. 1999a. A comparison of landscape mulches. J. Arbor. 25:88-97.

Duryea, M.L., J.B. Huffman, R.J. English, and W. Osbrink. 1999b. Will subterranean termites consume landscape mulches? J. Arbor. 25: $143-150$.

Einert, A.E., R. Guidry, and H. Huneycutt. 1975. Permanent mulches for landscape plantings of dwarf crape myrtles. Amer. Nurseryman 142:9-59, 62-65.

Eom, S.H., A.F. Senesac, I. Tsontakis-Bradley, and L.A. Weston. 2005. Evaluation of herbaceous perennials as weed suppressive groundcovers for use along roadsides or in landscapes. J. Environ. Hort. 23:198-203.

Fain, G.B., P.R. Knight, C.H. Gilliam, and J.W. Olive. 2003. Effect of fertilizer placement on prostrate spurge growth in container production. J. Environ. Hort. 21:177-180.

Fennimore, S.A. and D.J. Doohan. 2008. The challenges of specialty crop weed control, future directions. Weed Technol. 22:364-372.

Foo, C.L., K.C. Harrington, and M.B. MacKay 2011. Weed suppression by twelve ornamental ground cover species. New Zealand Plant Protection 64:149-154.

Froment, M.A., C.P. Britt, and J. Doney. 2000 Farm woodland weed control: Mulches as an alternative to herbicides around newly planting oak Quercus robar transplants. Asp. Appl. Biol. 20:81-86.

Froud-Williams, R.J., R.J. Chancellor, and D.S.H. Drennen. 1981. Potential changes in weed flora associated with reduced-cultivation systems in cereal production in temperate regions. Weed Res. 21:99-109.

Gill, H.K., R. McSorley, and M. Branham. 2011 Effect of organic mulches on soil surface insects and other arthropods. Fla. Entomol. 94:226-232.

Greenly, K. and D. Rakow. 1995. The effects of mulch type and depth on weed and tree growth. J. Arbor. 21:225-232.

Hanim, A., A. Nazera, S. Ab Kahar, and M.N Hamdan. 2014. Effects of different inorganic mulches on seed germination, weed biomass and growth. J. Trop. Agr. Fd. Sci. 42:29-36.

Henry, M.S. 1994. The contribution of landscaping to the price of single family houses: A study of home sales in Greenville, South Carolina. J. Environ. Hort. 12:65-70.

Hodges, A.W., C.R. Hall, and M.A. Palma. 2011a. Economic contributions of the green industry in the United States, 2007. South. Coop. Ser. Bull. No. 413.

Hodges, A.W., T. Stevens, M. Rahmani, and H. Khachatryan. 2011b. Economic contributions of the Florida Environmental Horticulture Industry in 2010. University of Florida/IFAS Food \& Resource Economics Department, Gainesville. 23 Dec. 2014. <http://www.fred.ifas.ufl. edu/economic-impact-analysis/pdf/Economic Contributions_Florida_Environmental_Horticulture_ Industry_2010.pdf $>$.

Horowitz, M., Y. Regev, and G. Herzlinger. 1983. Solarization for weed control. Weed Sci. 31: 170-179.

Iles, J.K. and M.S. Dosmann. 1999. Effect of organic and mineral mulches on soil properties and growth of 'Fairview Flam R' red maple trees. J. Arbor. 25:163-167.

Kanematsu, M., A. Hayashi, M.S. Denison, and T.M. Young. 2009. Characterization and potential environmental risks of leachate from shredded rubber mulches. Chemosphere 76:952-958.

Kirkland, K.J. and H.J. Beckie. 1998. Contribution of nitrogen fertilizer placement to weed management in spring wheat (Titicum aestivum). Weed Technol. 12:507-514.

Kolb, T.E. 1988. Allelopathic effects of Kentucky bluegrass on northern red oak and yellow poplar. J. Arbor. 14:281-283.

Kristoffersen, P., A.M. Rask, and S.U. Larsen. 2008. Non-chemical weed control on traffic islands: A comparison of the efficacy of five weed control techniques. Weed Res. 48:124-130.

Kuhns, L.J. 1992. Efficacy and phytotoxicity of three landscape herbicides with and without a light mulch. Proc. Northeastern Weed Sci. Soc. 46:85-89.

Larson, K.L., D. Casagrande, S.L. Harlan, and S.T. Yabiku. 2009. Residents' yard choices and rationales in a desert city: Social priorities, ecological impacts, and decision tradeoffs. Environ. Mgt. 44:921-937.

Laverne, R.J. and K. Winson-Geideman. 2003. The influence of trees and landscaping on rental rates at office buildings. J. Arbor. 29:281-290.

MacRae, A., N. Boyd, and M. D'Abreau. 2010. Nonchemical weed control for home landscapes and gardens. Fla. Coop. Ext. Serv. Pub. HS1170.

Mannering, J.V. and L.D. Meyer. 1963. The effects of various rates of surface mulch on infiltration and erosion. Soil Sci. Soc. Amer. Proc. 27:84 86.

Martin, C., H. Ponder, and C. Gilliam. 1987. Ability of polypropylene fabrics to inhibit the growth of six weed species. Alabama Agr. Exp. Sta. Rpt. 5:25-26.

Martin, C.A., K.A. Peterson, and L.B. Stabler. 2003. Residential landscaping in Phoenix, Arizona, U.S.: Practices and preferences relative to covenants, codes, and restrictions. J. Arbor. 29:9-17.

Mashingaidze, A.B., L.A. Lotz, W. Van der Werf, J. Chipomho, M.J. Kropff, and J. Nabwami. 2012. The influence of fertilizer placement on maize yield and growth of weeds. Sci. Conf Proc. p. 786-800.

Matheny, A.L. 2009. Home gardener preferences, perceptions, knowledge and behaviors associated with pest management strategies and information acquisition (Thesis). University of Maryland, College Park, MD. 175 p.

Maynard, A.A. 1998. Utilization of MSW compost in nursery stock production. Compost Sci. Util. 6:38-44.

Messenger, A.S. 1976. Root competition: Grass effects on trees. J. Abor. 2:228-230.

McPherson, E.G. 1998. Atmospheric carbon dioxide reduction by Sacramento's urban forest. J. Arbor. 24:215-223.

McPherson, E.G. and R.A. Rowntree. 1993. Energy conservation potential of urban tree planting. J. Arbor. 19:321-331. 
Morales, D.J. 1980. The contribution of trees to residential property value. J. Arbor. 6:305-308.

Morosz, A. 2004. Effect of soil salinity on nutrient uptake, growth, and decorative value of four ground cover shrubs. J. Plant Nutr. 27:977989.

Nassauer, J.I. 1988. The aesthetics of horticulture: Neatness as a form of care. HortScience 23:973977.

Neal, J.C. 2006. Bedding plant host preference for dodder. South. Nurs. Assoc. Res. Conf. 51:411412.

Nielson, A.P. and R.C. Wakefield. 1978. Competitive effects of turfgrass on the growth of ornamental shrubs. J. Agron. 70:39-42.

Niu, G. and D.S. Rodriguez. 2006. Relative salt tolerance of selected herbaceous perennials and groundcovers. Sci. Hort. 110:352-358.

Norcini, J.G., A. Bolques, and R.H. Stamps. 2010. Container nursery weed control: Sanitation practices to prevent weed seed contamination. Fla. Coop. Ext. Serv. Pub. ENH1050.

Norton, D.A. and M.A. Carpenter. 1998. Mistletoes as parasites: Host specificity and speciation. Trees 13:101-105.

Oliveira, M.T. and I.A. Merwin. 2001. Soil physical conditions in a New York orchard after eight years under different groundcover management systems. Plant Soil 234:233-237.

Parish, S. 1990. A review of non-chemical weed control techniques. Biol. Agr. Hort. 7:117-137.

Payne, B.R. 1973. The twenty-nine tree home improvement plan. Nat. Hist. 82:74-75.

Pittenger, D.R., D.A. Shaw, D.R. Hodel, and D.B. Holt. 2001. Responses of landscape groundcovers to minimum irrigation. J. Environ. Hort. 19:78-94.

Rappaport, B. 1992. Weed laws: A historical review and recommendations. Nat. Areas J. 12:216-217.

Rask, A.M. and P.K. Kristoffersen. 2007. A review of non-chemical weed control on hard surfaces. Weed Res. 47:370-380.

Richardson, B., C.H. Gilliam, G. Fain, and G. Wehtje. 2008. Container nursery weed control with pinebark mini-nuggets. J. Environ. Hort. 26:144-148.

Robbins, P. 2007. Lawn people: How grasses, weeds, and chemicals make us who we are. Temple University Press, Philadelphia, PA.

Robbins, P., A. Polderman, and T. Birkenholtz. 2001. Lawns and toxins: An ecology of the city. Cities 18:369-380.

Robbins, P. and J. Sharp. 2003a. Producing and consuming chemicals: The moral economy of the American lawn. Econ. Geogr. 79:425-451.

Robbins, P. and J. Sharp. 2003b. The lawn-chemical economy and its discontents. Antipode 35:955 979.

Robinson, D.W. 1988. Mulches and herbicides in ornamental plantings. HortScience 23:547552.

Sadiq, M., I. Alam, A. Elmubarek, and H.M. Almohdhar. 1989. Preliminary evaluation of metal pollution from wear of auto tires. Bull. Environ. Contam. Toxicol. 42:743-748.

Sandberg, L.A. and J. Foster. 2005. Challenging lawn and order: Environmental discourse and lawn care reform in Canada. Environ. Polit. 14:478-494.

Scott, K.I., E.G. McPherson, and J.R. Simpson. 1998. Air pollution uptake by Sacramento's urban forest. J. Arbor. 24:224-234.

Skroch, W.A., M.A. Powell, T.E. Bilderback, and P.H. Henry. 1992. Mulches: Durability, aesthetic value, weed control, and temperature. J. Environ. Hort. 10:43-45.

Simpson, J.R. 1998. Urban forest impacts on regional heating and cooling energy use: Sacramento County case study. J. Arbor. 24:201-214.

Smith, E.M. 1979. Mulches serve many purposes. Ohio St. Univ. Coop. Ext. Service LF-CP2-79.

Smolders, E. and F. Degryse. 2002. Fate and effect of zinc from tire debris in soil. Environ. Sci. Technol. 36:3706-3710.

Somireddy, U. 2012. Effect of herbicide-organic mulch combinations on weed control and herbicide persistence. Ohio St. Univ. Theses and Dissertation. 23 Dec. 2014. < https://etd.ohiolink. edu/>.
Steward, L.G., T.D. Sydnor, and B. Bishop. 2003. The ease of ignition of 13 landscape mulches. J. Arbor. 29:317-321.

Still, D.W. and F.T. Davies, Jr. 1993. Water use, water use efficiency and growth analysis of selected woody ornamental species under a non-limiting water regime. Sci. Hort. 53:213223.

Stinson, J.M., G.H. Briden, D.B. McConnell, and R. J. Black. 1990. Evaluation of landscape mulches. Proc. Florida State Hort. Soc. 103:372-377.

Sullivan, W.C. and F.E. Kuo. 1996. Do trees strengthen urban communities, reduce domestic violence? Arborist News 5:33-34.

Taylor, L. and V.K. Smith. 2000. Environmental amenities as a source of market power. Land Econ. 76:550-568.

Teasdale, J.R. and C.L. Mohler. 1999. The quantitative relationship between weed emergence and the physical properties of mulches. Weed Sci. 48:385-392.

Ulrich, R.S. 1986. Human response to vegetation and landscapes. Landsc. Urban Plan. 13:29-44.

Watson, G.W. 1988. Organic mulch and grass competition influence tree root development. J. Arbor. 14:242-245.

Wilen, C.A., U.K. Schuch, and C.L. Elmore. 1999. Mulches and subirrigation control weeds in container production. J. Environ. Hort. 17:174 180.

Winkel, V.K., J.C. Medrano, C. Stanley, and M.D. Walo. 1995. Effects of gravel mulch on emergence of galleta grass seedlings, p. 130-134. In: B.A. Roundy, E.D. McArthur, J.S. Haley, and D.K. Mann (ed.). Gen. Tech. Repo. INT-GTR315. USDA, Forest Service, Intermountain Research Station, Ogden, UT.

Whitcomb, C.E. 1979. Effects of black plastic and mulches on growth and survival of landscape plants. Okla. State Univ. Agr. Expt. Sta. Res. Rep. P-791:8-11.

Zhang, L. and Y. Xia. 2003. The application and studies of ground cover plants in landscape architecture. J. of Chinese Landscape Architecture 9:014. 